\title{
Keeping in Touch. A Survey of Lexicography Periodicals
}

\author{
R.R.K. Hartmann, Exeter, United Kingdom (r.r.k.hartmann@exeter.ac.uk)
}

\begin{abstract}
Journals and other serial publications are important to the work of lexicographers, so it is necessary to know what is available. On the basis of a list of 40 periodicals of relevance to lexicography, a comparative summary is attempted to give an impression of the major topics treated and formats used, including some desiderata for future improvements.
\end{abstract}

Keywords: LEXICOGRAPHY PERIODICALS, READERS' NEEDS, BIBLIOGRAPHIC TREATMENT

Opsomming: Om in voeling te bly. 'n Oorsig van leksikografietydskrifte. Tydskrifte en ander periodieke publikasies is belangrik vir leksikograwe se werk, dus is dit noodsaaklik om te weet wat beskikbaar is. Aan die hand van 'n lys van 40 tydskrifte wat tersaaklik is vir die leksikografie, is 'n kort vergelykende oorsig onderneem om ' $n$ indruk te kry van die hoofonderwerpe wat behandel en die formate wat gebruik word, insluitende ' $n$ aantal tekortkominge vir toekomstige verbetering.

Sleutelwoorde: LEKSIKOGRAFIETYDSKRIFTE, LESERSBEHOEFTES, BIBLIOGRAFIESE BEHANDELING

\section{Introduction}

What is the use of periodicals? This is an important question, as it can determine our attitude to progress in the field of lexicography. I experienced this recently while reviewing a book on phraseology (Hartmann 2009), a set of conference proceedings concerned with the linguistic study of multiword expressions, which did not give me a complete picture of how this might affect their treatment in dictionaries. Then I happened to come across a journal with a thematic section on 'Collocations in European lexicography and dictionary research' (more on this in Section 2 below), which helped me to place the whole subject in its proper context. What this example shows us is that periodicals can be extremely useful in providing information, although we still have to know what to expect, where to look for it, and how to decide what is relevant.

So what are the needs of readers, how do such publications meet them, and how do their editors and publishers know (or learn) to locate and present the required information? One representative case to examine is the journal Lexicographica (more on this in Section 2 below), which was started by Herbert Ernst Wiegand (Heidelberg) in the wake of the foundation of the European Association for Lexicography and in parallel with the book series Lexicographica Series Maior. With informal links to EURALEX and DSNA since 1985, it has produced 24 annual volumes of international repute. 
I shall attempt to provide a survey here of relevant periodicals, some similar to and some different from Lexicographica. There are no precedents for this (I could not find any other easily accessible guide like this anywhere), so I had to undertake the task with the help of the appended list, which provides data on a selection of 40 serial publications, i.e. journals, magazines and newsletters for the field of lexicography in the narrow sense as well as some for neighbouring disciplines, differentiating where it seems appropriate between international and national organs, with a deliberate intention to look beyond English-language media. The Appendix gives details on their titles, sponsors, editors, ISSNs, publishers and numbers of volumes (and issues p.a.) published. ${ }^{1}$

\section{A case study: Lexicographica}

Published once a year, Lexicographica has managed to follow (and often lead) major trends in the field, promoting a European and global outlook. The 13 papers on the theme of collocation in the most recent volume already mentioned (No. 24, 2008) are symptomatic of the journal's bridge-building approach, bringing together people from different countries, languages and specialisations under a capable editor - in this case Franz Josef Hausmann (Erlangen) - to reflect on recent developments in the subject under discussion: Henning Bergenholtz (Aarhus) on Danish, Peter Blumenthal (Cologne) on French, Sibilla Cantarini (Ferrara) on Italian, František Čermák (Prague) on Czech, Peter Durčo (Bratislava) on German and Slovakian, Martin Everaert (Utrecht) on Dutch, Thomas Herbst and Brigitta Mittmann (Erlangen) on English, Zíta Hollós (Budapest) on Hungarian, Vida Jesenšek (Maribor) on Slovenian, Sven-Göran Malmgren (Gothenburg) on Swedish, Tadeusz Piotrowski (Opole) on Polish, Bernhard Pöll (Salzburg) on Spanish and Portuguese, and Kathrin Steyer (IdS Mannheim) on German. Although such overviews can help to clarify the current position, I must admit that I am still somewhat puzzled by the conflicting interpretations and definitions of even the basic notion of 'collocation' (do such constructions consist of two or more lexical items, do they involve modified nouns (like stock-taking exercise), verbs (keep in touch), and/or other word classes (note down, on a humorous note), are they 'fixed' like idioms or more 'free', and is statistical frequency a factor?) as well as several tensions that remain between linguistic theory and lexicographic practice.

Other topics covered in thematic issues of Lexicographica guest-edited by appropriate experts have included dictionary criticism, dictionary history, dictionary structure (such as the treatment of meaning, examples and idioms), dictionary typology (such as monolingual vs. bilingual lexicography, cultural, thesaurus and LSP lexicography, authors' and learners' dictionaries), and dictionary IT (such as computer applications and corpus linguistics). In addition to the regular feature of a thematic part, Lexicographica contains papers on other topics, reports on events such as conferences and dictionary projects, book reviews and occasional lists of bibliographical references to new publications. 


\section{Taking stock}

Most bibliographies do not provide separate lists of periodicals. One exception is the international Bibliographie Linguistique, which started in 1949 and has appeared in over 50 volumes, although its list of excerpted lexicography journals covers only 17 of the periodicals discussed here; another is the International Bibliography of the Modern Language Association (MLA) which includes a Master List of Periodicals (now part of OCLC - see below); a third is the Bibliographie Thématique by Boccuzzi et al. (2007), which cites over 250 titles, although only a small proportion of these are devoted to the field of lexicography.

Many lists of bibliographic references to journals are incomplete or out of date (even the one on the EURALEX website), and there are very few attempts to extract the periodical literature in a systematic way (the journal Linguistics and Language Behavior Abstracts (LLBA) has recently agreed to increase its coverage of the periodicals discussed here to more than half of the 40 listed), a problem which is aggravated by the fact that journals themselves do not always keep track of their own papers in the form of regular indexes, which might be made worse by the reluctance on the part of editors and publishers to acknowledge the achievements of their competitors. Motivated by such deficiencies, I started a panoramic 'Zeitschriftenschau' many years ago (Hartmann 1964-1970) in an effort to make readers of a German journal of translation studies more aware of the literature in other journals of relevance to the subject. Similar compilations have been provided by Wiegand et al. in the above-mentioned annual journal Lexicographica, at regular intervals from Vol. 1 (1985) to Vol. 17 (2001), and also under the heading 'Zeitschriftenschau' in the journal Zeitschrift für germanistische Linguistik (since 2004).

Radical improvements have been made recently in the form of digital services such as the American Genamics-Openly and OCLC-JournalSeek database (part of the Online Computer Library Center at Dublin, Ohio), the ThomsonReuters Journal Citation Index, EBSCO's Electronic Journals Service, and the Spanish Dialnet library search system at the Universidad de la Rioja. In spite of their impressive coverage (MLA and OCLC claim to list over 17000 titles, and EBSCO over 19 000), not all lexicography periodicals are cited there; thus, Lexicographica is missing from LLBA, OCLC, Thomson-Reuters and EBSCO, although it can be found on Dialnet.

\section{Lexicography and dictionary research}

\subsection{International journals}

Our comparative survey can start with a description of the International Journal of Lexicography (IJL), which began a few years after Lexicographica as the journal of EURALEX with a full programme of essays, reports, review articles as well as lists and reviews of new publications. There have been three active editors 
since 1988, Robert Ilson (London), Tony Cowie (Leeds) and Paul Bogaards (Leyden), supported by two associate editors, a review editor and an international editorial board, ensuring that all aspects of lexicography are covered, particularly through the medium of thematic issues, most recently on the legacy of John Sinclair (Birmingham) for the study of collocations and the use of corpus linguistics, guest-edited by Patrick Hanks (Brno) in Vol. 21 No. 3 (2008), on planning bilingual dictionaries, edited by Willy Martin (Amsterdam) in Vol. 20 No. 3 (2007), on corpus-based studies of German idioms, edited by Christiane Fellbaum (Berlin/Princeton) in Vol. 19 No. 4 (2006), on the 250th anniversary of Samuel Johnson's Dictionary of the English Language, edited by Anne McDermott and Rosamund Moon (Birmingham) in Vol. 18 No. 2 (2005), on lexicography in Italy, edited by Carla Marello (Torino) in Vol. 17 No. 4 (2004), on multilingual databases for the benefit of bilingual lexicography, edited by Paul Bogaards in Vol. 17 No. 2 (2004) and on the FrameNet approach to lexicography, edited by Thierry Fontenelle (Microsoft, Redmond WI) in Vol. 16 No. 3 (2003).

There are not many truly international or continental or regional journals available for the field of lexicography. In addition to the IJL, the following three deserve to be singled out: Dictionaries, Lexikos and LexicoNordica, all with respectable histories and ambitious agendas. Several years before the foundation of EURALEX, the Dictionary Society of North America had been established (with the help of Edward Gates at Terre Haute IN), and by 1979 its journal had begun, entitled Dictionaries, with a series of editors from Richard W. Bailey (Michigan) and William Chisholm (Cleveland State) to Michael Adams (on leaving based at Indiana) and William Frawley (Chevy Chase MD). One of its innovations was a ten-year Index (in 1990 and 2000), although nowadays it has become easier to search for the contents of published issues, especially in journals with online connections. Another notable feature have been thematic issues dedicated in the last few years to the treatment of neologisms in lexicography and a tribute to Ladislav Zgusta (1924-2007) in Vol. 28 (2007), to 'hard problems' in dictionary-making in Vol. 27 (2006), to the memory of Allen Walker Read in Vol. 24 (2003), and to the completion of the Middle English Dictionary at the University of Michigan in Vol. 23 (2002).

Lexikos is the journal most familiar to its readers, so I need not go into details here except to acknowledge the regular and full coverage of most aspects of lexicography and its affiliation to the ever-growing African Association for Lexicography, although it had actually been initiated (by the Woordeboek van die Afrikaanse Taal at a meeting in Stellenbosch) some five years before the foundation of AFRILEX in 1995. The last volume, No. 18 (2008), offered 15 articles on a wide range of topics, dictionary genres and languages, a paper on lexicosoftware, a survey of dictionary use, a note on a pioneer lexicographer, a bibliography of material relevant to an etymological dictionary of Afrikaans, several reports on dictionary projects and other events, and a major review article on a new textbook. 
No journals have yet emerged from the areas of AUSTRALEX and ASIALEX, but there is one run by the Nordic Lexicography Society (NFL) LexicoNordica - which has become known particularly for its systematic treatment of thematic issues linked to an active programme of biennial conferences and annual symposia. Under the overall editorship of Henning Bergenholtz from Denmark and Sven-Göran Malmgren from Sweden, the last few volumes have covered topics like the user perspective (Vol. 15, 2008), Nordic encyclopedias and lexica (Vol. 14, 2007), historical dictionaries (Vol. 13, 2006) and electronic dictionaries (Vol. 12, 2005).

\subsection{National journals}

The journal Lexicographica has already been introduced, but in spite of its international links over the years it remains a national product, especially since the recent takeover of the publishing company Niemeyer by De Gruyter has brought about a change in the editorial team, concentrating on the interdisciplinary interests of five German academics.

The French journal Cahiers de lexicologie has been around for over half a century, undergoing several editorial and publishing changes. Topics covered include the French approach to dictionary research, reports on dictionary projects, 'hommages' to famous lexicographers, and comparative and historical accounts of important dictionaries as well as many issues in lexicological studies. To pick out just one sample issue, No. 88 (2006), it consists of 13 articles one by Jean Pruvost (Cergy-Pontoise) on metalexicographic theory, 11 by other authors on various features of specific dictionaries, and two on Josette ReyDebove (1929-2005) — and three reviews of Le Robert and Larousse dictionaries. The new editors are keen to broaden the interdisciplinary coverage and international appeal of the journal.

The Chinese bimonthly journal Cishu Yanjiu (Lexicographical Studies) has been active for three decades. Sponsored by the Lexicographical Society of China (which has 8 committees on the various types and traditions of dictionary-making, and since the early 1990s has held numerous national conferences on general lexicography and symposia on bilingual dictionaries) and produced by the Shanghai Lexicographical Publishing House, Cishu Yanjiu has covered the practice and theory of lexicography with an impressively wide range of shortish articles, reviews, reports and occasional lists of references (multiplying the average number of papers per issue (10) by the number of issues p.a. (6) and the number of volumes published so far (30) results in the staggering figure of 1 800). It is entirely in Mandarin Chinese, but always supplies an English translation of its table of contents.

Another leading journal devoted to a particular country and the language(s) used there is the Revista de Lexicografía. Promoted as a national organ not by an association, but by an academic body, the Department of Spanish and Latin Philology at the University of Coruña, under the editorship of Mar Cam- 
pos Souto and José Ignacio Pérez Pascual, it has been published in the form of annual volumes of about 6 to 9 papers each on mixed topics, and more recently it has been accompanied by 9 additional Anexos, which fulfil a function similar to that of thematic issues in Lexicographica, on such topics as the Spanish Royal Academy Dictionary (17 papers coordinated by the two journal editors, in Vol. $1,2006)$, the 'Coruña' Spanish Dictionary (description and extracts, directed by José-Álvaro Porto Dapena, in Vol. 9, 2007), bilingual and learners' dictionaries (13 papers edited by Mar Campos Souto et al., in Vol. 8, 2008); interestingly, Vol. 3 (2006) of the Anexos offers 16 papers, edited by Margarita Alonso Ramos, on the dictionary treatment of collocations, idioms and other phraseological expressions, with references to such pioneers as John Sinclair and Igor Mel'čuk. The Revista's format is simpler than that of Lexicographica, with all papers being in Spanish (from now on a wider range of languages are being encouraged) and a gradually rising number of reviews. In contrast to Lexicographica, there is an international committee advising the editors of both the journal and the annexes.

Other nationally based journals include Studi di Lessicografia Italiana in Italy, ${ }^{2}$ Onomasiology Online in Germany, Lexicon in Japan, and the journal of KOREALEX

Onomasiology Online is special in that it exemplifies the growing tendency towards publications on the internet with relation to a rather rare alternative approach in lexicography. Most traditional dictionaries have been 'semasiological' in that they start from given words and attempt to explain their meaning(s), while 'onomasiology' starts with a particular thing or notion and tries to find the various ways in which it can be designated, an approach that has been associated mainly with thesaurus and synonym lexicography, and also with onomastics and technical terminology (see Sections 5.2 and 5.3 below). This German e-journal explores the ways cognitive linguistics, knowledge management and corpus linguistics can be brought to bear on a better understanding of lexical and communicative processes. The three editors have the help of an international board of consultants both for questions of substance and for the use of English by authors of individual contributions.

Hanguk-sajeonhak, the journal of the Korean Lexicography Association, has been published in the form of 2 volumes per year since 2003, under the editorship of Sang-kyu Seo (Yonsei, Seoul) with the support of a 13-member national editorial committee, providing articles and reports on all aspects of lexicography, including the newsletter of KOREALEX.

Lexicon is the journal published annually by the Iwasaki Linguistic Circle, an informal research network chaired by Shigeru Takebayashi (Tokyo), concerned with progress in English lexicography for over three decades, particularly in terms of developing objective criteria to apply to dictionary criticism and the study of dictionary history.

There is also a small group of local journals which started as newsletters (see Section 6 below), but have grown into full-fledged bulletins, magazines or journals, some even with international connections, such as the Barnhart Dic- 
tionary Companion, which specialises in (American) English neologisms and features the Editor's Page on aspects of word-formation and lexicography, and the Kernerman Dictionary News which publishes reports on old and new dictionary projects from around the world, most recently (No. 16, 2008) on English, Japanese and Estonian, and on the future of Merriam-Webster.

We need to acknowledge that occasionally brilliant papers on lexicographic topics may be published in non-lexicographic journals, just as non-lexicographic topics may appear in lexicography journals. Two examples of the former are the thematic issues on the application of corpus linguistics to dictionaries and translation in a Polish journal (Kaszubski 2006) and on various aspects of dictionary use around the world in one published in Brazil (Welker 2007), but I cannot find any examples of the latter.

\section{Wider perspectives}

We have been concentrating on lexicography in the narrow sense of the word, but now we need to broaden the scope beyond it to other fields, beginning with Reference Reviews, one of the few journals which has managed to transcend many of the artificial boundaries that still exist today, e.g. between general and specialised dictionaries, between lexical and encyclopedic reference works, and between lexicography and its surrounding disciplines, thus contributing one answer to the intriguing question whether the whole of lexicography, together with other subjects mentioned below, might be moving towards what has been called 'reference science' (McArthur 1998) or 'informology' (Tarp 2007).

Started in the late 1980s by M.C.B University Press and now run by the Emerald Group in Northern England, Reference Reviews is unique in offering an open-minded but critical panorama 'of new reference materials prepared by librarians for librarians'. Thus, the final two issues of Vol. 22, Nos. 7 and 8 (2008), contain articles reviewing reference works, in part this time with special attention to 'output from lesser-known publishers', under the following subject headings: 'general' works (such as the New Walford Guide to Reference Sources reviewed by Stuart James, past editor of Reference Reviews, commenting on the irony that printed guides of this kind are still essential today in spite of the ever more widely available information on the internet), philosophy and religion (such as the Encyclopedic Sourcebook of Satanism), social sciences (such as the Oxford Handbook of the United Nations), business and management (such as the online Business Plans and Profiles Index), languages and literature (such as The Greenwood Encyclopedia of Folk Tales and Fairy Tales), science and technology (such as the online U.S. Patent and Trademark Office), arts (such as the Cambridge Companion to Ballet), geography, biography and history (such as The 'Daily Telegraph' Dictionary of Tommies' Songs and Slang 1914-18), area studies (such as A Companion to Latin American History), plus editorials and indexes.

Now we can branch out to neighbouring disciplines, such as descriptive linguistics (from phonetics and syntax to semantics and textology, with or 
without etymology and dialectology — see Section 5.1 below), the study and codification of names (see Section 5.2 below), the study and codification of language(s) for specific purposes (LSP) or technical terminology (see Section 5.3 below), and various other aspects of applied linguistics (from language teaching to translation, with or without such fields as library science and semiotics - see Section 5.4 below), all of them supported by information technology (see Section 5.5 below). Again, for some of these, although perhaps not for all, it may make sense to distinguish international periodicals from those with a more regional, national or local orientation.

\subsection{Language academies}

One sub-genre of periodicals that deserves to be mentioned is the one specialising in the linguistic study of the world's languages, such as (in order of their numbers of native speakers) Mandarin Chinese, English, Spanish, Hindi, Arabic, Portuguese, Bengali, Russian, Japanese, German, and French - without forgetting 'smaller' languages such as Albanian, Basque, Cherokee, Hebrew or Nama. Many of these have academies or similar bodies devoted to their detailed linguistic description, which often involves corpus archives and historical, general and dialect dictionary projects. Some of these institutions publish journals and newsletters (such as Trefwoord of the Frisian Academy in the Netherlands and Leksikografski Pregled ${ }^{3}$ of the Language Institute of the Bulgarian Academy of Sciences), although it is worth pointing out that even for some of these bodies and publications, lexicographic issues are not often considered of more than secondary importance.

We will now widen our view to a type of periodical which concentrates on the description of particular languages, but only brief summaries of five such publications can be given: American Speech, English Language and Linguistics, Language in India, Southern African Linguistics and Applied Language Studies, and Lexique.

American Speech is one of the oldest authorities on dialectology, but as any website search would confirm, it does not neglect lexicographic codification as an important topic; indeed, one of the original goals of its sponsor, the American Dialect Society, was to publish a dictionary of American English. The journal carries the typical articles and reviews, but also has regular features (such as the over 60-year-old column 'Among the New Words') and special issues, such as the Winter 2002 issue on Frederick Cassidy (1907-2000). A series of supplements and monographs which accompanies the journal, Publication(s) of the American Dialect Society, has had several volumes dedicated to lexicographic issues and achievements, such as dialect dictionaries, usage labelling and Allen Walker Read (1906-2002).

English Language and Linguistics is linked to a number of departments at British universities, namely Manchester, Edinburgh and University College London. The English Department at UCL is the home of the Survey of English 
Usage which hosted the Third Conference on the Linguistics of Contemporary English in July 2009 (together with colleagues from Queen Mary, University of London). Lexical studies form part of the editorial emphasis of ELL, such as the thematic issue No. 2 of Vol. 12 (2008) on intensifiers, guest-edited by Belén Mendez-Naya (Santiago de Compostela).

Language in India is a genuinely online journal attempting to build bridges between Indian scholars and linguists around the world. Its website and its pages are full of information on Indian languages such as Hindi, Punjabi, Gujarati, Kannada, Tamil, Telugu, Rajasthani, Urdu and Malayalam, including conferences, publications and research degrees, although occasionally the editors' rushing into e-text can detract from serious academic judgement and idiomatic fluency in the predominantly English discourse.

Southern African Linguistics and Applied Language Studies was established as a combination of the two journals of the Linguistic Society of Southern Africa and the Southern African Applied Linguistics Association with the purpose of reporting on research into all the languages of Southern Africa from both the theoretical-descriptive and the applied-practical points of view. It has a national editorial committee and an international advisory committee and publishes articles on a wide range of topics, research reports and book reviews, predominantly through the medium of English, occasionally on subjects of relevance to lexicography.

Lexique is the title of the Lille-based revue, which has appeared in 19 volumes since 1982, at least 6 of which have been dedicated to lexicological and lexicographic themes: Vol. 2 (1982) edited by Bernard Al and Jaap Spa on 'le dictionnaire', Vol. 4 (1986) edited by Claude Buridant on 'lexicographie au moyen âge', Vol. 9 (1990) edited by Michel Glatigny on 'les marques d'usage dans les dictionnaires (XVIIe-XVIIIe siècles)', Vol. 12-13 (1995) edited by Pierre Corbin and Jean-Pierre Guillerm on 'dictionnaires et littérature/littérature et dictionnaires', and Vol. 19 (2008) edited by Pierre Corbin and Nathalie Gasiglia on 'changer les dictionnaires?'.

\subsection{Onomastics}

Onomastics is concerned with the study of personal names and place names as well as designations for other objects, events and products, a fascinating but still rather underdeveloped discipline. Onoma, the journal of the International Council of Onomastic Sciences, was founded in 1950 and has recently been making an effort to catch up with its sequence of annual thematic volumes since No. 39 (2004), guest-edited by Botolv Helleland (Oslo) with 20 papers on the teaching of the subject in 12 different countries, in the United Nations and on the web, and No. 40 (2005), edited by Grant Smith (Eastern Washington) and Friedhelm Debus (Kiel), concentrating on literary onomastics. Other annual issues due to be published soon are Vol. 41 edited by Richard Coates (Bristol) on name theory, Vol. 42 edited by Staffan Nyström on urban topony- 
my, and Vol. 43 edited by Antje Zilg et al. on commercial names; other topics to be treated include African onomastics, the history of onomastics, and names and minorities.

Of other onomastic organs on offer, I shall just mention five: Names, the journal of the American Name Society, Nomina, the journal of the Society for Names Studies in Britain and Ireland, the French Nouvelle Revue d'Onomastique and the Rivista Italiana di Onomastica. Some are supported by international editorial advisory boards; most present a combination of articles, reviews and notices, often with references to relevant conferences, dictionary projects and published glossaries.

\subsection{Terminology}

In this section, we turn our attention to an area that is often neglected in lexicography, viz. technical terminology, a field that hovers awkwardly between the study of specialised discourse ('LSP') and various efforts to standardise the lexis used in scientific communication ('terminography'). Although there are many national institutions and even international conferences dedicated to this kind of specialisation, there seems to be a regrettable lack of cooperation between them, and teaching and research are still rather underdeveloped.

Ibérica is the journal of AELFE, the European Association of Languages for Specific Purposes, which contains articles (e.g. on the vocabulary and discourse features of particular disciplines, notably in Spanish and English), research notes (e.g. on various text genres and their teaching and translation) and book reviews (e.g. of descriptions of and textbooks on LSP and occasionally of terminological dictionaries).

Terminology has the ambitious sub-title International Journal of Theoretical and Applied Issues in Specialized Communication. Its two editors, Kyo Kageura (Tokyo) and Marie-Claude L'Homme (Montréal), take its 15th anniversary as an occasion for describing its raison d'être in Vol. 14 No. 2 (2008) by highlighting three sets of tensions: terminology studies vs. subject-domain disciplines, terminological theory vs. applied issues, and local terminology vs. global terminology. The journal attempts to present various aspects of these not only in the form of conventional articles, reports and reviews, but occasionally by means of 'special issues', such as the five devoted to term extraction in Japanese, recent trends in computational terminology, application-driven terminology engineering, pattern-based approaches to semantic relation extraction, and processing of terms in specialised dictionaries and terminological databases.

There are several other national and international journals, of which I will mention only two more. The Cahiers $d u$ Rifal (RIFAL being a research network linking the Organisation Internationale de la Francophonie and the Communauté Française de Belgique) has appeared in approximately annual volumes since 1989, initially under the title Terminologie Nouvelle, with the aim of promoting interdisciplinary connections between terminology studies and transla- 
tion, e.g. in Vol. 26 (2007), which has the theme 'Terminology, culture and society' and draws on papers from two conferences at Dakar (Bangladesh) and Gatineau (Canada).

Fachsprache, the International Journal of Specialized Communication, based at an Austrian publisher, has been quite influential in presenting and linking some of the recurring topics and recent trends in LSP, celebrating its 30th anniversary with a new editorial team and an international advisory board, adding Spanish to its main languages English, French and German, and developing a newsletter as part of its website.

\subsection{Other aspects of applied linguistics}

The distinction made in earlier sections between international and national periodicals seems less relevant here in a territory where interdisciplinary contact and collaboration are difficult enough as an objective in such fields as applied linguistics, language teaching, translation, semiotics, library science and genealogy; and it is only possible for me to give a brief impression of them.

Applied Linguistics (AL) is a truly global periodical, supported by the International Association for Applied Linguistics (famous for the powerful impact of its 15 triennial congresses since 1966), the American Association for Applied Linguistics and the British Association for Applied Linguistics. Among the applications of linguistic knowledge to the solution of practical problems mentioned on the AL website are language learning, teaching and testing, translation, bilingual education, discourse analysis and stylistics, language planning and lexicography. Periodicals for applied linguistics, particularly those specialising in language learning and teaching (either of a mother tongue/first language, LT1, or a foreign/second language, LT2) are too numerous to mention, especially those which concentrate on English, so AL will have to be their only representative here.

Babel is the journal of the International Federation of Translators, with an active tradition since 1955, when it was founded by Pierre-François Caillé, with financial support from UNESCO. The current editor is René Haeseryn, who has the backing of both an editorial board and an advisory committee. There are 4 issues per year, with papers in French, English and a number of other languages. One representative issue, Vol. 52 No. 1 (2006), contains 4 papers on different aspects of translation, an update on 'The Life of FIT' (and some of its publications), a report on a UNESCO series on literary translation, and bibliographical and lexicographic references (including two reviews).

Founded by Alexander Lane and led by a series of editors, including the translator and lexicographer Günther Haensch (and other academics at Augsburg and Leipzig), the journal Lebende Sprachen has been run by the dictionary publisher Langenscheidt since 1958 and recently been taken over by Niemeyer/De Gruyter, with the support of the German Federation of Translators. It often carries innovative articles on all aspects of literary and technical trans- 
lating and interpreting, (bilingual and multilingual) glossaries of specialised vocabulary, bibliographies and reviews of relevant publications and reports on relevant events.

Founded in 1969 as the organ of the International Association for Semiotic Studies, the journal Semiotica reports on research and reviews the literature, occasionally with thematic issues, on the role of letters, sounds, pictures and other signs and symbols in the graphic, phonic, visual and acoustic media and their effectiveness in specific communicative contexts and genres. The interpretation and codification of vocabulary and terminology come up for treatment now and again, e.g. in the fields of medicine, law and computing in issue No. 172 (2008).

Having met the journal Reference Reviews at the start of Section 5, we can acknowledge other periodicals connected with library science and book publishing. Linguistics and Language Behavior Abstracts, already mentioned in Section 3 above, has done much for over 40 years to catalogue the literature contained in linguistic periodicals. The Indexer, published in print as well as in electronic format by the (British) Society of Indexers on behalf of indexing societies around the world, including those in Australia/New Zealand, Canada, China, Germany, the Netherlands and the U.S., covers a wide range of issues from different conventions across languages, subjects and ages to an ever widening range of appropriate tools. The Genealogists' Magazine addresses a range of topics in its most recent issues, from the tracing of ancestors by various means and through specific archives, records and registers to the role of emigration and immigration and the ancestry of famous people, plus obituaries and library news.

\subsection{Information technology and corpus linguistics}

As early as 1988, Laurence Urdang (1927-2008) was the pioneering guest-editor of a thematic issue of Lexicographica on what by now has become a fairly commonplace feature, the use of computers in dictionary-making. Other aspects of information technology which are occasionally relevant to lexicography include database development, archive and corpus design, artificial intelligence, natural language processing, and machine translation.

Computational Linguistics, published by the Association for Computational Linguistics well-known for its international conferences, has been addressing some of these topics since 1974. In the four issues of 2008, they include statistical parsing, semantic role labelling, machine learning and the construction of corpora. On the latter, the International Journal of Corpus Linguistics has been particularly relevant in two recent thematic issues, Vol. 11 No. 3 (2006) focusing on lexical cohesion, guest-edited by John Flowerdew and Michaela Mahlberg, and Vol. 12 No. 2 (2007) on the work of John Sinclair, guest-edited by Rosamund Moon.

More journals are, of course, available for English and other languages 
and countries, but it is impossible to cover every aspect of this ever more dominating field. Meanwhile, it is easy to observe a trend for more computerisation, which not only helps all aspects of lexicography, but affects the way more and more periodical publications are developing electronic versions (documented, among others, by IngentaComment, a service provided by the British-American company Publishing Technology).

\section{Newsletters}

Related to journals are newsletters, typically issued by lexicography associations, dictionary publishers or dictionary projects, such as the EURALEX Newsletter (which originally appeared as a paperback Bulletin after the LEXeter'83 conference and was then published in IJL, first as a Bulletin every other issue and since 1990 as a regular 4-issue feature). The DSNA Newsletter has been published by the Dictionary Society of North America since 1977 to report on biennial meetings, other conferences, important projects and outstanding lexicographers.

There is a tendency that bulletin-like publications can gradually grow into journals, as has happened to the KDN (of Kernerman Dictionaries Ltd.) and the $\mathrm{BDC}$ (of Barnhart/LexikHouse). At the same time, websites have taken over from printed newsletters for the purpose of publicising events, annual reports and lists of people and references, as has happened in the case of many national and international associations (e.g. the AFRILEX website offers crossreferences to its nine newsletters published since 1995) as well as publishing companies (e.g. Oxford University Press's OED News since 1995 have become part of the regular updates on the online pages of the Oxford English Dictionary).

\section{Conclusion}

I have tried to single out some of the representative types of journals, magazines and newsletters which have a bearing on lexicographic specialisation(s), both in printed and in online format (as in Onomasiology Online and Language in India), although it is of course impossible to cover all relevant institutions, countries, and languages. As we have seen, the topics covered in these periodicals range widely, from practice to theory, and from one genre of reference work to another (cf. Hartmann 2007); in their entirety they make a significant contribution to defining and supporting lexicography.

There are inherent limitations in the editing and publication of all periodicals, owing to academic-personal, commercial-public and other problems, some of which lead to difficulties such as reduced sales, irregular delivery, changes of title or topics treated. Examples of these are the closing down of Lexicology, the International Journal on the Structure of Vocabulary after only three years, the slow start of a number of journals (such as Ibérica between 1969 and 1999), 
changes in the sequence of volumes or annual numbers of issues published (e.g. Semiotica is one of those journals which numbers issues cumulatively and volumes by year rather than annual number), or even a complete change of editors/sponsors/publishers (as in the Cahiers de lexicologie after 40 years or in Fachsprache after 30 years).

A number of desiderata seem to be in order, then, to improve the periodical scene further. One of these is international standardisation of publishing practices (such as the now almost globally uniform ISSN, cited for all periodicals listed in the Appendix). A second desideratum is better bibliographic treatment (e.g. by abstracting and indexing - we noted that abstracting journals like LLBA do not list all important titles from the lexicographic field, and several of the world's indexing systems like Dialnet, OCLC, Thomson-Reuters or Ingenta do not include the full range of lexicography periodicals either). A third desideratum is wider academic recognition by universally respected bodies (such as the European Science Foundation which includes 19 of the 40 journals discussed above and lists them in its European Reference Index for the Humanities classified into one of three grades, from A to C). A fourth desideratum is better awareness and provision of more critical reviews of periodicals (such as the one of Lexique by Dupont and Bonnet 1999). A fifth desideratum is more accurate, up-to-date and reliable websites for the institutions and publishers responsible for journals.

It is impossible to cover every single periodical in a survey of this kind. Not all linguistic, regional and (inter)disciplinary serials could be listed some may even have escaped my searches altogether, in which case I apologise to those concerned. However, I hope that my attempt at sharing some of my experiences as a compiler, researcher, teacher and author has at least given readers an impression of the wide range of periodical publications that are out there, produced for us all to benefit from. ${ }^{4}$ Keep in touch and stay connected!

\section{Notes}

1. I have benefited from many lists (e.g. by ESF and OCLC, see below) as well as from the websites of publishers and sponsors of periodicals, and I have had some help from over $90 \%$ of all the publishing companies and journal editors involved. (A few whose details I could not verify had to be omitted.) I am particularly grateful to a number of friends and personal contacts for sending me relevant information (e.g. Kaoru Akasu, Gilles-Maurice de Schryver, Young-kuk Jeong, Robert Lew, Rosamund Moon, Jean Pruvost, Adam Smith, Kathrin Steyer and Herbert Welker).

2. This is one of the journals I had to omit as I could not verify the details by reference to its website or its editor/publisher.

3. This is another periodical whose publication details were difficult to verify, so I have omitted it from the list in the Appendix.

4. If you would like to make a contribution to my project of an International Directory of Lexicography Institutions (IDLI), of which the subject of Periodicals forms one of 12 sections, you can contact me by email: r.r.k.hartmann@exeter.ac.uk 


\section{References}

Bibliographie Linguistique/Linguistic Bibliography ed. by the Permanent International Committee of Linguists. Vol. 1 (1949) to Vol. 49 (1999) published by Spectrum at Utrecht and Antwerpen; from Vol. 50 (2000) published online, eds. S. Tol and H. Olbertz. Leyden: Brill.

Boccuzzi, C. et al. 2007. Bibliographie thématique et chronologique de métalexicographie 1950-2006. Bibliotheca della Ricerca. Bibliographica 10. Fasano: Schena Editore.

Dupont, N. and V. Bonnet. 1999. La Revue Lexique. International Journal of Lexicography 12(2): 99106.

Hartmann, R.R.K. 1964-1970. Zeitschriftenschau [I to XV]. Lebende Sprachen (München) Vol. 9 (1964) to 15 (1970).

Hartmann, R.R.K. 2007. Pure or Hybrid? The Development of Mixed Dictionary Genres. Facta Universitatis, Series Linguistics and Literature (University of Niš) 3.2: 193-208.

Hartmann, R.R.K. 2009. Review of Phraseology. An Interdisciplinary Perspective ed. by Sylviane Granger and Fanny Meunier. International Journal of Lexicography 22(1): 87-89.

Kaszubski, P. (Ed.). 2006. Assessing the Potential of Corpora. Poznan Studies in Contemporary Linguistics 41: 3-274.

McArthur, T. 1998. What then is Reference Science? McArthur, T. Living Words. Language, Lexicography, and the Knowledge Revolution: 215-222. Exeter: University of Exeter Press.

Tarp, S. 2007. Lexicography in the Information Age. Lexikos 17: 170-179.

Welker, H.A. (Ed.). 2007. O uso de dicionários. Horizontes de Lingüística Aplicada (Brasília) 6(2): 5294.

Wiegand, H.E. et al. 1985-2001. Continuous Bibliography. Lexicographica, from Vol. 1 (1985) to 17 (2001).

Wiegand, H.E. et al. 2004-2009. Zeitschriftenschau. Zeitschrift für germanistische Linguistik, from Vol. 31 (2003-04) to $36(2008-09)$. 


\section{Appendix: List of cited periodicals}

\begin{tabular}{|c|c|c|c|}
\hline $\begin{array}{l}\text { Title of serial } \\
\text { (Sponsoring body) }\end{array}$ & $\begin{array}{l}\text { Editor(s) } \\
\text { ISSN } \\
\text { [E for online] }\end{array}$ & Publisher & $\begin{array}{l}\text { Number of vol- } \\
\text { umes (and issues } \\
\text { p.a.) published }\end{array}$ \\
\hline $\begin{array}{l}\text { American Speech (AS). A } \\
\text { Quarterly of Linguistic Usage } \\
\text { (American Dialect Society) }\end{array}$ & $\begin{array}{l}\text { Michael Adams } \\
0003-1283 \\
\text { E: } 1527-2133\end{array}$ & $\begin{array}{l}\text { Duke University Press, } \\
\text { Durham NC, USA }\end{array}$ & $\begin{array}{l}83 \text { (x } 4 \text { issues } \\
\text { p.a.) since 1925; } \\
\text { available online }\end{array}$ \\
\hline $\begin{array}{l}\text { Applied Linguistics (AL) } \\
\text { (Association Internationale } \\
\text { de Linguistique Appliquée, } \\
\text { American Association for } \\
\text { Applied Linguistics, British } \\
\text { Association for Applied } \\
\text { Linguistics) }\end{array}$ & $\begin{array}{l}0142-6001 \\
\text { E: } 1477-450 X \\
\end{array}$ & $\begin{array}{l}\text { Oxford University Press, } \\
\text { Oxford, GB }\end{array}$ & $\begin{array}{l}29 \text { (x } 4 \text { issues } \\
\text { p.a.) since 1980; } \\
\text { available online }\end{array}$ \\
\hline $\begin{array}{l}\text { Babel. Revue Internationale de } \\
\text { la Traduction / International } \\
\text { Journal of Translation } \\
\text { (Fédération Internationale } \\
\text { des Traducteurs) }\end{array}$ & $\begin{array}{l}\text { René Haeseryn } \\
\text { 0521-9744 } \\
\text { E: } 1569-9668\end{array}$ & $\begin{array}{l}\text { J. Benjamins Publishing } \\
\text { Co., Amsterdam, NL }\end{array}$ & $\begin{array}{l}54 \text { (x } 4 \text { issues } \\
\text { p.a.) since 1955; } \\
\text { available online }\end{array}$ \\
\hline $\begin{array}{l}\text { (The) Barnhart Dictionary } \\
\text { Companion (BDC). A Quar- } \\
\text { terly of New Words }\end{array}$ & $\begin{array}{l}\text { David K. Barn- } \\
\text { hart } \\
0736-1122\end{array}$ & $\begin{array}{l}\text { Lexik House, Hyde Park } \\
\text { NY, USA }\end{array}$ & $\begin{array}{l}13 \text { (x } 4 \text { issues } \\
\text { p.a.) since 1982; } \\
\text { online planned }\end{array}$ \\
\hline $\begin{array}{l}\text { Cahiers de lexicologie. Revue } \\
\text { internationale de lexicologie et } \\
\text { lexicographie } \\
\text { (L.D.I. @ Univ. Paris } 13 \text { and } \\
\text { Univ. Cergy Pontoise) }\end{array}$ & $\begin{array}{l}\text { Gaston Gross, } \\
\text { Gérard Petit } \\
0007-9871\end{array}$ & $\begin{array}{l}\text { Éditions Garnier, } \\
\text { Paris, FR }\end{array}$ & $\begin{array}{l}48 \text { (x } 2 \text { issues } \\
\text { p.a.) since 1957; } \\
\text { online planned }\end{array}$ \\
\hline $\begin{array}{l}\text { (Les) Cahiers du Rifal } \\
\text { (Réseau International Fran- } \\
\text { cophone d'Aménagement } \\
\text { Linguistique) }\end{array}$ & $\begin{array}{l}\text { Martine Garsou } \\
1015-5716\end{array}$ & $\begin{array}{l}\text { RIFAL c/o TERMISTI, } \\
\text { Institut Supérieur de } \\
\text { Traducteurs et Inter- } \\
\text { prètes, Bruxelles, BE }\end{array}$ & $\begin{array}{l}27 \text { (x } 1 \text { issue p.a.) } \\
\text { since } 1989\end{array}$ \\
\hline $\begin{array}{l}\text { Cishu Yanjiu/Lexicographical } \\
\text { Studies } \\
\text { (Zhongguo Cishu Xuehui/ } \\
\text { Lexicographical Society of } \\
\text { China) }\end{array}$ & $\begin{array}{l}\text { CHAO Feng, } \\
\text { XU Xiamin } \\
1000-6125 \\
\end{array}$ & $\begin{array}{l}\text { Cishu Chubanshe/ Lexi- } \\
\text { cographical Publishing } \\
\text { House, Shanghai, CN }\end{array}$ & $\begin{array}{l}30(\times 6 \text { issues } \\
\text { p.a.) since } 1979\end{array}$ \\
\hline $\begin{array}{l}\text { Computational Linguistics } \\
\text { (CL) } \\
\text { (Association for Computa- } \\
\text { tional Linguistics) }\end{array}$ & $\begin{array}{l}\text { Robert Dale } \\
\text { 0891-2017 } \\
\text { E: } 1530-9312 \\
\end{array}$ & $\begin{array}{l}\text { MIT Press, Cambridge } \\
\text { MA, USA }\end{array}$ & $\begin{array}{l}34 \text { (x } 4 \text { issues } \\
\text { p.a.) since 1974; } \\
\text { available online }\end{array}$ \\
\hline $\begin{array}{l}\text { Dictionaries. Journal of the } \\
\text { Dictionary Society of North } \\
\text { America }\end{array}$ & $\begin{array}{l}\text { William Frawley } \\
0197-6745\end{array}$ & $\begin{array}{l}\text { DSNA c/o Lisa Berg- } \\
\text { lund, Department of } \\
\text { English, Buffalo State } \\
\text { College, Buffalo NY, USA }\end{array}$ & $\begin{array}{l}29 \text { (x } 1 \text { issue p.a.) } \\
\text { since } 1979\end{array}$ \\
\hline DSNA Newsletter & $\begin{array}{l}\text { Katherine Isaacs } \\
\text { no ISSN }\end{array}$ & DSNA $\rightarrow$ Dictionaries & $\begin{array}{l}32(\times 2 \text { issues } \\
\text { p.a.) since 1977; } \\
\text { available online }\end{array}$ \\
\hline $\begin{array}{l}\text { English Language and Lin- } \\
\text { guistics (ELL) }\end{array}$ & $\begin{array}{l}\text { Bas Aarts, David } \\
\text { Denison, April } \\
\text { McMahon } \\
\text { 1360-6743 } \\
\text { E: } 1469-4379 \\
\end{array}$ & $\begin{array}{l}\text { Cambridge University } \\
\text { Press, Cambridge, GB }\end{array}$ & $\begin{array}{l}12 \text { (x } 3 \text { issues } \\
\text { p.a.) since } 1997 \\
\text { available online }\end{array}$ \\
\hline
\end{tabular}




\begin{tabular}{|c|c|c|c|}
\hline EURALEX Newsletter & Paul Bogaards & $\begin{array}{l}\rightarrow \text { Intern. Journal of Lexi- } \\
\text { cography }\end{array}$ & $\begin{array}{l}25(x 4 \text { issues } \\
\text { p.a.) since } 1984\end{array}$ \\
\hline $\begin{array}{l}\text { Fachsprache / International } \\
\text { Journal of Specialized Commu- } \\
\text { nication }\end{array}$ & $\begin{array}{l}\text { Jan Engberg, Su- } \\
\text { sanne Göpferich, } \\
\text { Nina Janich } \\
1017-3285\end{array}$ & $\begin{array}{l}\text { W. Braumüller, Vienna, } \\
\text { AT }\end{array}$ & $\begin{array}{l}30(\times 4 \text { issues } \\
\text { p.a.) since 1979; } \\
\text { online planned }\end{array}$ \\
\hline $\begin{array}{l}\text { (The) Genealogists' Maga- } \\
\text { zine. Journal of the Society of } \\
\text { Genealogists }\end{array}$ & $\begin{array}{l}\text { Michael Gandy } \\
0016-6391\end{array}$ & SoG, London, GB & $\begin{array}{l}30(\mathrm{x} 4 \text { issues } \\
\text { p.a.) since } 1925\end{array}$ \\
\hline $\begin{array}{l}\text { Hanguk-sajeonhak/Journal } \\
\text { of the Korean Association for } \\
\text { Lexicography }\end{array}$ & $\begin{array}{l}\text { Sang-kyu Seo } \\
1598-8694\end{array}$ & KOREALEX, Seoul, KR & $\begin{array}{l}6 \text { ( } \times 2 \text { issues p.a.) } \\
\text { since } 2003\end{array}$ \\
\hline $\begin{array}{l}\text { Ibérica. Journal of the Euro- } \\
\text { pean Association of Languages } \\
\text { for Specific Purposes }\end{array}$ & $\begin{array}{l}\text { Ana Bocanegra- } \\
\text { Valle } \\
0153-0364\end{array}$ & $\begin{array}{l}\text { AELFE c/o Departament } \\
\text { d'Estudis Anglesos, Uni- } \\
\text { versitat Jaume I de Cas- } \\
\text { telló, Castelló de la Plana, } \\
\text { ES }\end{array}$ & $\begin{array}{l}10(\times 2 \text { issues } \\
\text { p.a.) since } 1999\end{array}$ \\
\hline $\begin{array}{l}\text { (The) Indexer. The Interna- } \\
\text { tional Journal of Indexing } \\
\text { (Society of Indexers) }\end{array}$ & $\begin{array}{l}\text { Maureen } \\
\text { MacGlashan } \\
0019-4131 \\
\text { E: } 1756-0632\end{array}$ & SI, Sheffield, GB & $\begin{array}{l}26(x 4 \text { issues } \\
\text { p.a.) since } 1958 ; \\
\text { available online }\end{array}$ \\
\hline $\begin{array}{l}\text { International Journal of } \\
\text { Corpus Linguistics (IJCL) }\end{array}$ & $\begin{array}{l}\text { Michaela Mahl- } \\
\text { berg } \\
1384-6655 \\
\text { E: } 1569-9811\end{array}$ & $\begin{array}{l}\text { J. Benjamins Publishing } \\
\text { Co., Amsterdam, NL }\end{array}$ & $\begin{array}{l}13(x 4 \text { issues } \\
\text { p.a.) since 1996; } \\
\text { available online }\end{array}$ \\
\hline $\begin{array}{l}\text { International Journal of } \\
\text { Lexicography (IJL) } \\
\text { (European Association for } \\
\text { Lexicography) }\end{array}$ & $\begin{array}{l}\text { Paul Bogaards } \\
\text { 0950-3846 } \\
\text { E: } 1477-4577\end{array}$ & $\begin{array}{l}\text { Oxford University Press, } \\
\text { Oxford, GB }\end{array}$ & $\begin{array}{l}21(x 4 \text { issues } \\
\text { p.a.) since } 1988 ; \\
\text { available online }\end{array}$ \\
\hline $\begin{array}{l}\text { Kernerman Dictionary News } \\
(\mathrm{KDN})\end{array}$ & $\begin{array}{l}\text { Ilan Kernerman } \\
1565-4745\end{array}$ & $\begin{array}{l}\text { K. Dictionaries, Tel Aviv, } \\
\text { IL }\end{array}$ & $\begin{array}{l}16 \text { (x } 1 \text { issue p.a.) } \\
\text { since } 1994\end{array}$ \\
\hline Language in India & $\begin{array}{l}\text { Madasamy Thi- } \\
\text { rumalai et al. } \\
\text { 1930-2940 }\end{array}$ & $\begin{array}{l}\text { M.S. Thirumalai, } \\
\text { Bloomington MN, USA }\end{array}$ & $\begin{array}{l}9(\times 12 \text { issues } \\
\text { p.a.) since 2001; } \\
\text { online only }\end{array}$ \\
\hline $\begin{array}{l}\text { Lebende Sprachen (LES). } \\
\text { Zeitschrift für fremde Sprachen } \\
\text { in Wissenschaft und Praxis } \\
\text { (Bundesverband der Dol- } \\
\text { metscher und Übersetzer) }\end{array}$ & $\begin{array}{l}\text { Peter A. Schmitt, } \\
\text { Reinhold Werner } \\
0023-9909 \\
\text { E: } 1868-0267\end{array}$ & $\begin{array}{l}\text { Max Niemeyer Verlag, } \\
\text { Tübingen and W. de } \\
\text { Gruyter, Berlin, DE }\end{array}$ & $\begin{array}{l}53(\mathrm{x} 4 \text { issues } \\
\text { p.a.) since 1956; } \\
\text { available online }\end{array}$ \\
\hline $\begin{array}{l}\text { Lexicographica. International } \\
\text { Annual for Lexicography/Re- } \\
\text { vue Internationale de Lexico- } \\
\text { graphie/Internationales Jahr- } \\
\text { buch für Lexikographie } \\
\text { (Dictionary Society of North } \\
\text { America, European Asso- } \\
\text { ciation for Lexicography) }\end{array}$ & $\begin{array}{l}\text { Ulrich Heid, Ste- } \\
\text { fan Schierholz, } \\
\text { Wolfgang } \\
\text { Schweickard, } \\
\text { Herbert Ernst } \\
\text { Wiegand, Werner } \\
\text { Wolski } \\
\text { 0175-6206 }\end{array}$ & $\begin{array}{l}\text { Max Niemeyer Verlag, } \\
\text { Tübingen and W. de } \\
\text { Gruyter, Berlin, DE }\end{array}$ & $\begin{array}{l}24 \text { (x } 1 \text { issue p.a.) } \\
\text { since 1985; } \\
\text { available online }\end{array}$ \\
\hline $\begin{array}{l}\text { Lexicon } \\
\text { (Iwasaki Linguistic Circle) }\end{array}$ & $\begin{array}{l}\text { Hideo Masuda } \\
\text { 0385-566X }\end{array}$ & $\begin{array}{l}\text { ILC c/o Kenkyusha Co. } \\
\text { Ltd., Tokyo, JP }\end{array}$ & $\begin{array}{l}38 \text { ( } x 1 \text { issue p.a.) } \\
\text { since } 1972\end{array}$ \\
\hline $\begin{array}{l}\text { LexicoNordica } \\
\text { (Nordisk Forening for Lek- } \\
\text { sikografi) }\end{array}$ & $\begin{array}{l}\text { Henning Bergen- } \\
\text { holtz, Sven- } \\
\text { Göran Malmgren } \\
0805-2735\end{array}$ & $\begin{array}{l}\text { NFL c/o Språkrådet, } \\
\text { Oslo, NO }\end{array}$ & $\begin{array}{l}15 \text { (x } 1 \text { issue p.a.) } \\
\text { since } 1994\end{array}$ \\
\hline
\end{tabular}




\begin{tabular}{|c|c|c|c|}
\hline $\begin{array}{l}\text { Lexikos } \\
\text { (African Association for } \\
\text { Lexicography) }\end{array}$ & $\begin{array}{l}\text { J.C.M.D. du } \\
\text { Plessis } \\
\text { 1684-4904 }\end{array}$ & $\begin{array}{l}\text { Buro van die WAT, Stel- } \\
\text { lenbosch, ZA }\end{array}$ & $\begin{array}{l}18 \text { (x } 1 \text { issue p.a.) } \\
\text { since } 1991\end{array}$ \\
\hline $\begin{array}{l}\text { Lexique } \\
\text { (Université Lille } 3 \text { Labora- } \\
\text { toire Savoirs Textes Lan- } \\
\text { gages UMR 8163) }\end{array}$ & $\begin{array}{l}\text { Georgette Dal } \\
\text { (et al.) } \\
0756-7138\end{array}$ & $\begin{array}{l}\text { Presses Universitaires du } \\
\text { Septentrion, Lille, FR }\end{array}$ & $\begin{array}{l}19 \text { (x } 1 \text { issue p.a.) } \\
\text { since } 1982\end{array}$ \\
\hline $\begin{array}{l}\text { Linguistics and Language } \\
\text { Behavior Abstracts (LLBA) }\end{array}$ & $\begin{array}{l}\text { Lynette Hunter } \\
0888-8027\end{array}$ & $\begin{array}{l}\text { Cambridge Scientific } \\
\text { Abstracts, Bethesda MD, } \\
\text { USA }\end{array}$ & $\begin{array}{l}42(x 5 \text { issues } \\
\text { p.a.) since } 1967 ; \\
\text { available online }\end{array}$ \\
\hline $\begin{array}{l}\text { Names. A Journal of Onomas- } \\
\text { tics } \\
\text { (American Name Society) }\end{array}$ & $\begin{array}{l}\text { Frank Nuessel } \\
0027-7738 \\
\text { E: } 1756-2279\end{array}$ & $\begin{array}{l}\text { Maney Publishing, Cam- } \\
\text { bridge MA, USA }\end{array}$ & $\begin{array}{l}56(\times 4 \text { issues } \\
\text { p.a.) since } 1953 ; \\
\text { available online }\end{array}$ \\
\hline $\begin{array}{l}\text { Nomina. Journal of the Society } \\
\text { for Name Studies in Britain } \\
\text { and Ireland }\end{array}$ & $\begin{array}{l}\text { Maggie Scott } \\
0141-6340 \\
\end{array}$ & $\begin{array}{l}\text { SNSBI c/o University of } \\
\text { Salford, Salford, GB }\end{array}$ & $\begin{array}{l}31 \text { (x } 1 \text { issue p.a.) } \\
\text { since } 1978\end{array}$ \\
\hline $\begin{array}{l}\text { (La) Nouvelle Revue d'Ono- } \\
\text { mastique (NRO) } \\
\text { (Société Française d'Ono- } \\
\text { mastique) }\end{array}$ & $\begin{array}{l}\text { Martina Pitz } \\
0755-7752 \\
\end{array}$ & $\begin{array}{l}\text { SFO c/o Université Jean } \\
\text { Moulin Lyon 3, FR }\end{array}$ & $\begin{array}{l}51 \text { (x } 1 \text { issue p.a.) } \\
\text { since } 1949 ; \\
\text { online planned }\end{array}$ \\
\hline $\begin{array}{l}\text { Onoma. Journal of the Inter- } \\
\text { national Council of Onomastic } \\
\text { Sciences }\end{array}$ & $\begin{array}{l}\text { Doreen Gerritzen } \\
0078-463 X \\
\text { E: } 1783-1644\end{array}$ & $\begin{array}{l}\text { Editions Peeters, Leuven, } \\
\text { BE }\end{array}$ & $\begin{array}{l}40 \text { (x } 1 \text { issue p.a.) } \\
\text { since } 1950 ; \\
\text { available online }\end{array}$ \\
\hline $\begin{array}{l}\text { Onomasiology Online } \\
\text { (OnOn) }\end{array}$ & $\begin{array}{l}\text { Alfred Bammes- } \\
\text { berger, Joachim } \\
\text { Grzega, Marion } \\
\text { Schöner } \\
\text { 1616-9692 } \\
\end{array}$ & $\begin{array}{l}\text { Katholische Universität } \\
\text { Eichstätt, Eichstätt-Ingol- } \\
\text { stadt, DE }\end{array}$ & $\begin{array}{l}8 \text { (x } 1 \text { issue p.a.) } \\
\text { since 2000; online } \\
\text { only }\end{array}$ \\
\hline Reference Reviews (RefRev) & $\begin{array}{l}\text { Tony Chalcraft } \\
0950-4125\end{array}$ & $\begin{array}{l}\text { Emerald Group, Bingley, } \\
\text { GB }\end{array}$ & $\begin{array}{l}22(x 8 \text { issues } \\
\text { p.a.) since } 1987 ; \\
\text { available online }\end{array}$ \\
\hline $\begin{array}{l}\text { Revista de Lexicografía } \\
\text { (with thematic Anexos since } \\
\text { 2006) }\end{array}$ & $\begin{array}{l}\text { José Ignacio } \\
\text { Pérez Pascual, } \\
\text { Mar Campos } \\
\text { Souto } \\
1134-4539 \\
\end{array}$ & $\begin{array}{l}\text { Departamento de } \\
\text { Filoloxía Española e } \\
\text { Latina, Universidade da } \\
\text { Coruña, A Coruña, ES }\end{array}$ & $\begin{array}{l}13 \text { (x } 1 \text { issue p.a.) } \\
\text { since 1995; } \\
\text { online planned }\end{array}$ \\
\hline $\begin{array}{l}\text { Rivista Italiana di Onomas- } \\
\text { tica (RIOn) } \\
\text { (Laboratorio Internazionale } \\
\text { di Onomastica, Roma) }\end{array}$ & $1124-8890$ & $\begin{array}{l}\text { Società Editrice Romana, } \\
\text { Roma, IT }\end{array}$ & $\begin{array}{l}13(\times 2 \text { issues } \\
\text { p.a.) since } 1995\end{array}$ \\
\hline $\begin{array}{l}\text { Semiotica. Journal of the } \\
\text { International Association for } \\
\text { Semiotic Studies }\end{array}$ & $\begin{array}{l}\text { Marcel Danesi } \\
0037-1998 \\
\text { E: } 1613-3692 \\
\end{array}$ & W. de Gruyter, Berlin, DE & $\begin{array}{l}39 \text { (x } 5 \text { issues } \\
\text { p.a.) since } 1969 ; \\
\text { available online }\end{array}$ \\
\hline $\begin{array}{l}\text { Southern African Linguistics } \\
\text { and Applied Language } \\
\text { Studies (SALALS) } \\
\text { (Linguistic Society of South- } \\
\text { ern Africa and Southern } \\
\text { African Applied Linguistics } \\
\text { Association) }\end{array}$ & $\begin{array}{l}1607-3614 \\
\text { E: } 1727-9461\end{array}$ & $\begin{array}{l}\text { National Inquiry Services } \\
\text { Centre, Grahamstown, } \\
\text { ZA }\end{array}$ & $\begin{array}{l}27 \text { (x } 4 \text { issues } \\
\text { p.a.) since } 1983 ; \\
\text { available online }\end{array}$ \\
\hline
\end{tabular}




\begin{tabular}{|c|c|c|c|}
\hline $\begin{array}{l}\text { Terminology. International } \\
\text { Journal of Theoretical and } \\
\text { Applied Issues in Specialized } \\
\text { Communication }\end{array}$ & $\begin{array}{l}\text { Kyo Kageura, } \\
\text { Marie-Claude } \\
\text { L'Homme } \\
0929-9971 \\
\text { E: } 1569-9994 \\
\end{array}$ & $\begin{array}{l}\text { J. Benjamins Publishing } \\
\text { Co., Amsterdam, NL }\end{array}$ & $\begin{array}{l}14 \text { ( } \times 2 \text { issues } \\
\text { p.a.) since 1994; } \\
\text { available online }\end{array}$ \\
\hline $\begin{array}{l}\text { Trefwoord, elektronisch lexi- } \\
\text { cografisch tijdschrift } \\
\text { (Fryske Akademy) }\end{array}$ & $\begin{array}{l}\text { Anne Dykstra et } \\
\text { al. } \\
\text { no ISSN }\end{array}$ & $\begin{array}{l}\text { Fryske Akademy, Leeu- } \\
\text { waarden, NL }\end{array}$ & $\begin{array}{l}9 \text { (x } 1 \text { issue p.a.) } \\
\text { since 1999; online } \\
\text { only }\end{array}$ \\
\hline
\end{tabular}

